\title{
Students' Interactivity with Digital Content Makes Difference in Learning
}

\author{
Iş1l Yenidoğan ${ }^{1}$
}

Abstract-This paper describes the results of the use of interactive digital material in teaching. The material, i.e. e-book, is created using Apple's iBooks Author ${ }^{\circledR}$ and is used with an iPad $^{\circledR}$ in a classroom. The student body varied greatly in terms of their educational background in high school: math and science students, social science students, and math and social science students. The results show that irrespective of students' background interactive digital material has positive effect in learning. Students, who were taught with interactive digital material performed about $8 \%$ better than those who were taught the same content using paper based material.

Keywords-Interactive digital material, e-book, iBook Author, iPad, Generation Z, digital devices in classroom, learning.

\section{Introduction}

In today's digital landscape, in which we try to facilitate students learning, "the world is getting more and more technology centered, focused and driven" [1]. Marc Prensky made the rather bold statement in 2001 and then added the following: "It is very likely that our students' brains have physically changed - and are different from ours - as a result of how they grew up ... surrounded by and using computers, videogames, digital music players, video cams, cell phones, and all the other toys and tools of the digital age" [2]. Today these students are called Generation Z. Although there is no clear agreement on the definition of this generation, on thing is sure that this is the generation born to today's ICT products. They are using today's technological toys for almost for any activity seamlessly. There seems to be no difficulty in learning how to use those devices/toys for these youngsters.

Although it has been reported in the literature widely that the use of digital devices in a classroom is still a debatable issue, it is accepted by majority that their use has positive effects on the Generation $\mathrm{Z}$ students' learning and attitudes [3, 4]. In a recent survey done for Laureate University, in 21 counties and 37 schools with a student population of 20.800 , students were asked as to "What kind of university do they imagine in the future?". Almost half of the attendees (43\%) believe that there will be free and online context at universities. The $59 \%$ of attendees and $60 \%$ of students envisage that they will use social media to share their knowledge and use digital context to learn. Also the $68 \%$ of attendees believe that there will be online libraries that students can reach course materials, books and other resources for free [5].

Kadir Has University

${ }^{1,2}$ Engineering and Natural Science College, Department of Management

Information Systems, ${ }^{3}$ Educational Technologies Department
Actually most of these expectations of the last group of attendees seem to be meeting via on-line course systems, most of which have substantial number of free course material and libraries. Examples of these on-line-course systems are Udemy [6], Coursera [7], Edx [8], and Code [9].

Studies show that visual effects, simulation, and animation etc. in or along with the teaching material have positive effect on learning and retention of information learned [10-13].

There are plenty of literatures showing the effect of visual aids, simulation, games, etc., which we will call as interactive learning material from here on. O'Hara and Pritchard classify the effect of technology on learning for children aged 6-12 and they claim that technology has strong effect on;

- enhancing literacy development,

- impacting language acquisition,

- $\quad$ providing greater access to information,

- $\quad$ supporting learning, motivating students, and

- $\quad$ enhancing their self-esteem [14].

Sharples goes one step further and suggests the mobile technologies for life-long learners [15]. This suggests that technology is not just for children aged 6-12 as the ref. [14] suggestion or for the generation $\mathrm{Z}$ as the refs in [10-13] suggestions, it is also good for improving the learning for grownups.

With the progress of technology used in education, different names have been used, such as distance learning, digital learning, e-learning, etc. The latest is called m-learning. Sharples defines m-learning as "the next generation of $e$ Learning and is based on mobile devices" [15]. In addition to this name we use the term interactive digital learning material to refer to general m-learning devices (tablets, smart phones, wearable devices etc.) through which one could deliver digital interactive content to enhance the learning process.

On one hand the technology is rapidly advancing and it is moving towards mobile (students use of tablets, smart phones, wearable devices etc. increases), on the other hand the Generation $\mathrm{Z}$ is about to arrive or has already arrived to the university. Thus, we need to have a different approach to teach or use additional (visual and/or interactive digital) aids in teaching.

To this end we have prepared an interactive digital content regarding the everyday computer literacy subject and tested on newly arrived English prep school students of Kadir Has University, Istanbul, Turkey. We report the results of this study in the paper. 


\section{A Basic Literature Review}

There seems to be two main theory groups (approaches) in the learning spectrum: Behaviorism and Constructivism. Each main theory group has many sub-theorems as well. In the Behaviorist approach there is directed instruction, whereas in the Constructivist approach there is non-directed instruction [16]. Studies regarding the effect of technology (visual aids, vides, web, mobile, etc.) on learning are generally grouped based on these two approaches.

There have been many studies on the effect of visual information, such as videos, pictures, drawings, simulations, animations etc., on learning and almost without an argument all agree that there is a positive effect of those aids with varying degrees of effectiveness. There is almost a unison agreement that duration of the visual aids can vary w.r.t. the audience, however, those visual aids are not replacement for basic instructional teaching.

O'Hara and Sellen's investigation of computer users' preference of reading from paper prints and from online reveals that reading from online is more preferred due to its great potential to support the augmentation of conventional paper-based reading [17].

Tatar, et. al. suggested that mobile devices assist students to master difficult concepts by letting them explore and interact with information on their own pace [18].

Mayer, identified six major principles of multimedia design for forming interactive digital materials to create a balance between the verbal and visual systems for effective learning outcomes [19]:

\section{1) Multimedia/Multiple Representation \\ 2) Contiguity principle \\ 3) Split-Attention principle \\ 4) Individual Differences principle \\ 5) Coherence principle \\ 6) The resulting effect of the coherence principle is called "redundancy effect."}

Dede claimed as early as in eightees that "any visual media delivery system capable of supporting learner interactivity while at the same time facilitating interconnectivity of images and symbols has the potential to become an extremely powerful educational tool" [20].

Sharples offers a framework for theorising regarding mobile learning, to complement theories of infant, classroom, workplace and informal learning [15]. He offers the following: "There is a need to re-conceptualize learning for the mobile age, to recognize the essential role of mobility and communication in the process of learning, and also to indicate the importance of context in establishing meaning, and the transformative effect of digital networks in supporting virtual communities that transcend barriers of age and culture".

Bull discusses how educators could use the cognitive constructivist theory of multimedia (CCTM) for designing interactive digital learning materials. He suggests that "CCTM advocates for the design of instruction using pictures, videos, audios and words that tap into the prior ex- periences of the learner, promote active learning, collaboration, personal autonomy, personal growth and alternative assessment that is aligned with multiple intelligences of learners" [21].

Sessoms claims that technology integration changes the process of teaching and learning to an interactive learning environment via its transformative nature. He claims by saying that, "the framework applied to the new form of teaching, known as interactive teaching and learning, represents the intersection of theory (constructivism), interactive hardware (interactive boards), and Web 2.0 tools such as Kids and Cookies" [21].

Merkt et. al. conduct two empirical studies to examine the the effectiveness of interactive features in videos in comparison to an illustrated textbook [22].

A short list of literature we summarized here and the references within this literature suggest that from kinder garden students to grownups all benetif from visiual aids and interactive matrial while learning a subject. Thus the use of interactive digital material in conjuntion with m-learning will no doubtly help higher education students learn more while having fun [23-24].

\section{Technology}

The distance learning has evolved into e-learning and nowadays it is evolving into m-learning. The technology for each case is different but what is important in all types is the content and how students or whether they are able to interact with the digital content while learning. Some of the recent ebooks, such as those created by Apple's iBooks Author ${ }^{\circledR}$, provides one such type.

The most common e-book types and their extensions are:

$\begin{array}{lll}\text { - } & \text { EPUB (IDPF) } & \text {.epub } \\ \text { - } & \text { Kindle } & \text {.azw } \\ \text { - } & \text { Microsoft Reader } & \text {.lit } \\ \text { - } & \text { Mobipocket } & \text {.prc, .mobi } \\ \text { - } & \text { Portable Document Format } . p d f \\ \text { - } & \text { Open Document Format } & \text {.odf } \\ \text { - } & \text { iBooks Author (iBA) } & \text {.iBooks }\end{array}$

Although there are plenty of other formats for digital documents, two of them clearly stand out: For many years the most common format was PDF (portable documents format), nowadays, there is a new format, EPUB (version 3.0), which may change all the habits about digital formats.

As the e-books and m-learning software and the technologies are getting better and better we would like to mention both the advantages and disadvantages of them before embarking on the details of the test and results we have.

\section{1) Advantages/Disadvantages}

Advantages:

- Price: E-books are cheaper than printed ones.

- Portability: A user can carry lots of e-books in a small device or store on a cloud and access anywhere, anytime. 
Proc. of the Second Intl. Conf. on Advances in Information Processing and Communication Technology - IPCT 2015 Copyright $(\odot$ Institute of Research Engineers and Doctors, USA .All rights reserved.

ISBN: 978-1-63248-044-6 doi: 10.15224/ 978-1-63248-044-6-121

- Easy to Use: Users can find the subject they search with a push of a button.

- Functionality: Users can change font, color, voice level, screen brightness etc. This is a great chance for people with disabilities.

- Accessibility: Users can access books on Internet without going to a library or to a bookshop.

- Interactive Content: E-books provide interactivity with audio, video, and photos, which makes e-books more interesting and fun.

- Green Computing: It is a green computing product, no need to real paper.

- Easy to take notes as one reads a book with all types of color, pictures, remainders etc.

Disadvantages:

- Lack of Standards: It is a big disadvantage that there is no international standard for e-books yet. This brings the miss-match problem between e-book types. For example, an e-book created with iBooks Author can be read with devices only with iOS or OSX operating system.

- Feeling: It does not give the real book feeling.

\section{Experimental Results}

The main goal of the study was to evaluate the effect of interactive digital material on learning. Two groups of students were selected: the test group, which is a student body currently continuing English prep school for all faculties. The composition of this group is the same as the second group, which we call the survey group. The second group is composed of university students, from freshmen to seniors, of faculties of Law, Art and Design, Communication, Economics-Administrative and Social Sciences, and Engineering and Natural Sciences. This group has more than 3000 students and was subject to a questionnaire to figure out the profile of the first group, i.e., the test group. Total of 238 students out of this group responded to the online questionnaire sent to their student e-mail accounts. The respond rates for different faculties are:

$\begin{array}{ll}\text { Law } & : \% 4 \\ \text { Art and Design } & : \% 4 \\ \text { Communication } & : \% 5\end{array}$

Economics-Administrative and Social Sciences $\quad: \% 5$

Engineering and Natural Sciences $\quad: \% 11$.

The students as shown in Table I and II, in both groups have different high-school educational backgrounds. Those going for Engineering have a math and science education, whereas the Law and Business students have math and social science background, and the Communication students have social science background.

The students of the first unbiased group, for which the profile is obtained via a questionnaire from the second group, are also divided into two groups: One group of these students were asked to read a basic computer literacy related material

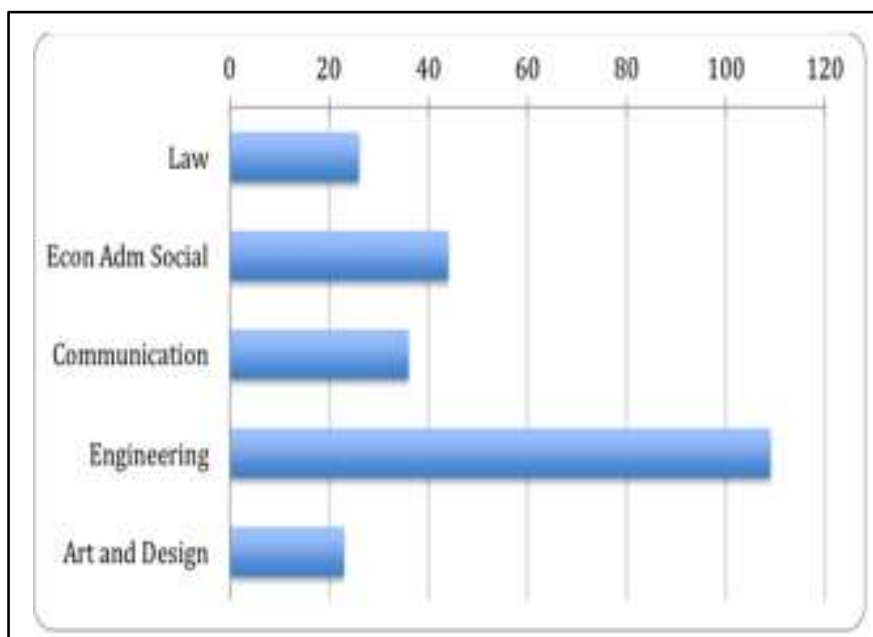

Figure 1. The survey group's profile distribution.

prepared by iBooks Authors ${ }^{\circledR}$, and served with iPad ${ }^{\circledR}$, whereas the other group was asked to read the same content from a paper-print text. Having read the material all students were subject to the same multiple-choice test questions. The result of this test is shown in Figure 4.

TABLE I. DETAILS OF BOTH THE SURVEY AND TEST GROUPS.

\begin{tabular}{|l|l|l|}
\hline \multicolumn{3}{|c|}{ Kadir Has University Attendees' Information } \\
\hline Campus & Main & Prep School \\
\hline Profile & $\begin{array}{l}\text { Undergraduates } \\
\left(1^{\text {st }}-4^{\text {th }} \text { years }\right)\end{array}$ & $\begin{array}{l}\text { Prep students for all } \\
\text { faculties }\end{array}$ \\
\hline Group Name & Survey & Test \\
\hline Age Range & $19-25$ & $18-20$ \\
\hline $\begin{array}{l}\text { Number of } \\
\text { attendees }\end{array}$ & 238 & 86 \\
\hline
\end{tabular}

TABLE II. THE DETAILS OF THE TEST GROUP.

\begin{tabular}{|l|c|c|c|}
\hline Faculty & $\begin{array}{c}\text { Paper } \\
\text { Based } \\
\text { Exam }\end{array}$ & $\begin{array}{c}\text { Ipad } \\
\text { Based } \\
\text { Exam }\end{array}$ & Total \\
\hline $\begin{array}{l}\text { Engineering \& } \\
\text { Natural Sciences }\end{array}$ & 8 & 11 & 19 \\
\hline Art \& Design & 4 & 7 & 11 \\
\hline Communication & 8 & 10 & 18 \\
\hline $\begin{array}{l}\text { Economics- } \\
\text { Administration \& } \\
\text { Social Sciences }\end{array}$ & 16 & 14 & 30 \\
\hline Law Total & 40 & 46 & 86 \\
\hline & & 4 & 8 \\
\hline
\end{tabular}


Proc. of the Second Intl. Conf. on Advances in Information Processing and Communication Technology - IPCT 2015 Copyright (c) Institute of Research Engineers and Doctors, USA .All rights reserved.

ISBN: 978-1-63248-044-6 doi: 10.15224/ 978-1-63248-044-6-121

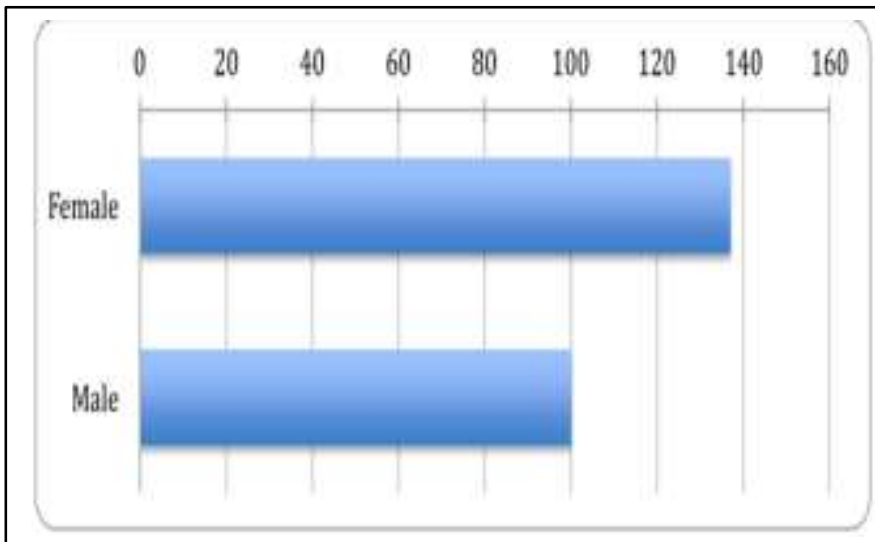

Figure 2. The survey group's gender distribution.

\section{v. Discussion and Conclusion}

Before the study, our expectations about the difference between the rates of success for test group dividends were higher than what the project result turned out to be. However, the study achieved the goal stated at the beginning, that is, there will be a positive effect of interactive digital material on learning. The use of digital interactive content has really an effect on learning but not as much as one would expect. The students who were taught with the digital content were $8 \%$ more successful than the ones taught with traditional material. It is observed that some of the students lost their focus while studying with an iPad, probably due to their age and mood of being a prep school student. Moreover, it might be distractive if the interactive content such as sounds, videos and 3D objects are used too much. The situation shows that digital interactive material must be simple and focused to the subject. The pleasure they receive from the experience were high.

\begin{tabular}{|c|c|c|c|c|c|c|c|}
\hline & 1 & 2 & 3 & 4 & 5 & Total & Average \\
\hline rd like to be with technology. & 1 & 3 & 24 & 72 & 138 & 238 & 4.44 \\
\hline $\begin{array}{l}\text { I am interested in new } \\
\text { technological produxts. }\end{array}$ & 6 & 18 & 45 & 78 & 91 & 238 & 3.97 \\
\hline $\begin{array}{l}\text { Ird tike to spend time in } \\
\text { shopping malls which have } \\
\text { technology markets. }\end{array}$ & 18 & 23. & 49 & 59 & 89 & 238 & 3.75 \\
\hline $\begin{array}{l}\text { Inever go out without my eell } \\
\text { phone. }\end{array}$ & 9 & 11 & 18 & 32 & 168 & 238 & 4.42 \\
\hline $\begin{array}{l}\text { I have changed my mobile } \\
\text { phone within a year. }\end{array}$ & 71 & 19 & 12 & 20 & 116 & 238 & 3.38 \\
\hline $\begin{array}{l}\text { I examine technical specs of } \\
\text { cell phones. }\end{array}$ & 10 & 10 & 37 & 68 & 112 & 237 & 4.11 \\
\hline \multicolumn{8}{|c|}{$\begin{array}{l}\text { Figure } 3 \text {. The second group students' attitude towards technology } \\
\text { use (Please indicate contribution level of yours. Strongly } \\
\text { Disagree }=1 \text {, Disagree }=2 \text {, Neutral }=3 \text {, Agree }=4 \text {, Strongly } \\
\text { Agree }=5(\mathrm{~N}=238) \text { ). }\end{array}$} \\
\hline
\end{tabular}

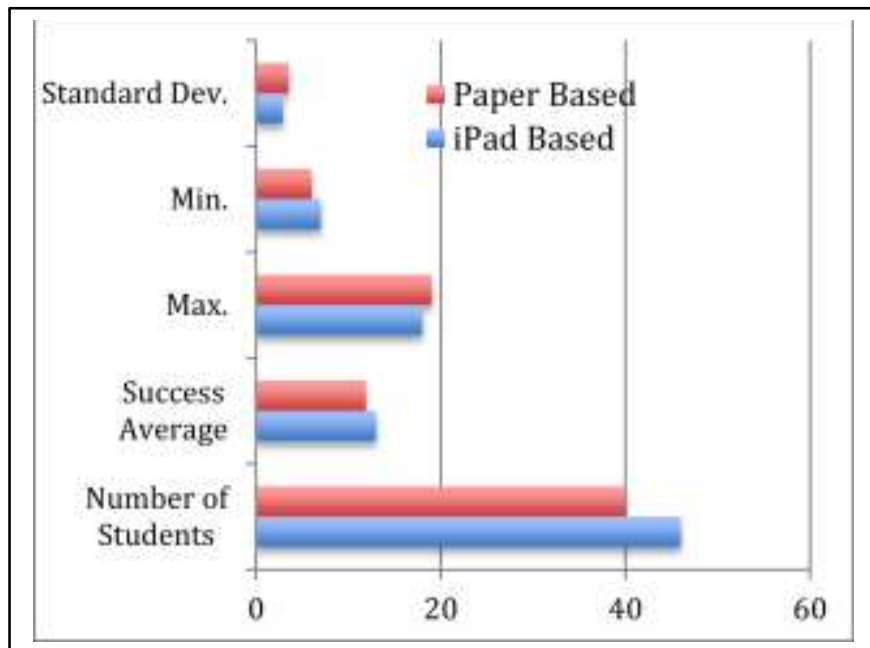

Figure 4. Response of test group to learning material.

The answer to the question "Would you like to have a class that related to technology?" was "Absolutely Yes" for $55 \%$ of the students. The same rate of students said they definitely wanted to be taught with digital materials. The percentage of the students who said "never" to the same questions was only $4 \%$ (one student per faculty)

$58 \%$ of students said that it is a pleasure, $34 \%$ of them said it might be more pleasure if the subject was not that technical to study with iPad. Only $6.9 \%$ of them found the experience "boring".

In conclusion, an interactive digital content was created by using Apple's iBooks Authors ${ }^{\circledR}$ to assess its effect on learning of a diversely backgrounded student body. Before the test is applied, the students' profile is obtained from a student group, the survey group, with the same background. The interactive test material, the computer literacy booklet, and its paperbased version were given to two groups of students at the same time and asked to take a multiple-choice test afterwards. The study time for both groups was one hour. Those students using $\mathrm{iPad}^{\circledR}$ with the interactive digital material have performed, on the average, $8 \%$ better than those learning from paper-based material. This preliminary result indicates that there is a promising way of teaching to this coming Generation $\mathrm{Z}$ for better learning.

\section{Acknowledgment}

I. Yenidoğan thanks her newly graduated MIS students Batuhan Balım, Kadir Melih Güleç, and Yusuf Burak Tatlıcan for their invaluable work in the preparation of the test material and conducting the tests. I. Yenidogan also thanks to Apple Solution Expert Naksan Technology for their contribution to this project by providing $\mathrm{iPad}^{\circledR}$ for students' use both for learning the material and doing the test.

\section{References}

[1] Plante, T., "Digital Natives vs Digital Immigrants? Which are you? In Do the Right Thing", July 2012. Accessed from http://www.psychologytoday.com/blog/do-the-right-thing/2012 on 9 September 2013.

[2] Prensky, M., "Digital Natives Digital Immigrants: Do They Really Think Differently?", On the Horizon, Volume 9, No. 6, December 2001. 
[3] Fitch, J. L. (2004) "Student Feedback in the College Classroom: A Technology Solution", Educational Technology Research and Development, Vol 52, 2004, pp 171-181.

[4] Lam, P. Aiden Tong , A. "Digital Devices in Classroom - Hesitations of Teachers-to-be", Electronic Journal of e-Learning Volume 10 Issue 4 2012 .

[5] Zogby J, Zogby J. Jr., "2014 Global Survey of Students" submitted to: Matthew Yale, Laureate International Universities", Zogby Analytics 2014.

[6] http://www.udemy.com

[7] http://www.coursera.com

[8] http://www.edx.org

[9] http://www.code.org

[10] Holzinger, A., Nischelwitzer,, A., Meisenberger, M., A"Mobile Phones as a Challenge for m-Learning: Examples for Mobile Interactive Learning Objects (MILOs)“', Proceedings of the 3rd Int'l Conf. on Pervasive Computing and Communications Workshops (PerCom 2005 Workshops).

[11] Theodore, P., "Collaborative versus Cooperative Learning: A Comparison of the Two Concepts Which Will Help Us Understand the Underlying Nature of Interactive Learning", http://www.capecod.net/TPanitz/Tedspage

[12] Stokes, S., "Visual Literacy in Teaching and Learning: A Literature Perspective" Electronic Journal for the Integration of Technology in Education, Vol. 1, No. 1, pp. 10-19, 2014.

[13] Bobek, E., Tversky, B., "Creating Visual Explanations Improves Learning", In Proceedings of the 36th annual conference of the cognitive science society. Cognitive Science Society, Austin, TX. 2014.

[14] O'Hara, S., Pritchard, R., "Teaching Vocabulary with Hypermedia, 612", Prentice Hall (2008-09-12), ISBN 10: 0131724444 / ISBN 13: 9780131724440

[15] Sharples, M., "The Design of Mobile Technologies for Lifelong Learning", Computers \& Education Vol. 34, p. 177-193, 2000.

[16] Forrester D., Jantzie N., "Learning Theories", http://www.acs.ucalgary.ca/\%7Egnjantzi/learning_theories.htm

[17] O'Hara, Sellen, A. "A Comparison of Reading Paper and On-Line Documents", Proceedings of CHI '97, Conference on Human Factors in Computing Systems, Atlanta, GA.

[18] Tatar, D., Roschelle J., Vahey, P., Penuel, WR, "Handhelds go to school: Lessons learned", Computer 36 (9), p. 30-37, 2003.

[19] Anderson, T. (Editor), "The Theory and Practice of Online Learning" $5^{\text {th }}$ Edition, AU Press, Athabasca University, 2011.

[20] Ding-Hau Huang., D.H., Chiou, W. K., "The Effect of Using Visual Information Aids on Learning Performance During Larger Scale Procedural Task"

[21] Bull P. H., "Cognitive Constructivist Theory of Multimedia: Designing Teacher-Made Interactive Digital", Creative Education, Vol. 4, No. 9, p. 614-619, 2013.

[22] Sessoms, D., "Interactive instruction: Creating interactive learning environments through tomorrow's teachers", International Journal of Technology in Teaching and Learning, 4(2), p. 86-96, 2008.

[23] Merkt, M., Wiegand, S., Heier, A., Schwan, S., "Learning with videos vs. learning with print: The role of interactive features", Learning and Insgtruction Vol. 21, p. 687-704, 2011.

[24] Kanuka, H., "Understanding e-Learning Tehnologies in Practice Throuhg Plilosophies-in-Practice in [19]. 